\title{
The Impact of Family Involvement on SMEs' Performance: Theory and Evidence
}

\author{
Alfredo De Massis \\ University of Bergamo \\ Via Pasubio 7B, 24044 Dalmine (BG) - Italy \\ alfredo.demassis@unibg.it \\ Josip Kotlar (corresponding author) \\ University of Bergamo \\ Via Pasubio 7B, 24044 Dalmine (BG) - Italy \\ josip.kotlar@unibg.it \\ Giovanna Campopiano \\ University of Bergamo \\ Via Pasubio 7B, 24044 Dalmine (BG) - Italy \\ giovanna.campopiano@unibg.it \\ Lucio Cassia \\ University of Bergamo \\ Via Pasubio 7B, 24044 Dalmine (BG) - Italy \\ lucio.cassia@unibg.it
}

Accepted for publication at Journal of Small Business Management

The authors are indebted to the Associate Editor, Eddy Laveren, and the anonymous reviewers for their insightful and developmental feedback, which led to substantial improvements in our work. The authors are also thankful to Joseph Astrachan, Jess Chua, and Mattias Nordqvist for their helpful comments on earlier versions of the article. 


\title{
The Impact of Family Involvement on SMEs' Performance: Theory and Evidence
}

\begin{abstract}
By complementing agency theory with behavioral assumptions, we explore the effects of family involvement on SMEs' performance. We identify three separate dimensions of family involvement and hypothesize non-linear, direct and interaction effects on the performance of an SME. The evidence on 787 SMEs suggests that an inverted U-shaped relationship exists between family ownership and performance, and ownership dispersion among family members negatively affects performance. Balancing family and non-family members in the TMT is found to be beneficial to SMEs' performance, but the family ratio in the TMT becomes crucial only at high levels of family ownership.
\end{abstract}

\section{Introduction}

In the literature on economics, as well as that related to management and entrepreneurship, the incidence of studies of family firms has increased in recent years (De Massis et al. 2012; Debicki et al. 2009), and a number of recent empirical studies have demonstrated that, even though the definition of a "family business" remains a matter of some debate, the direct involvement of family members in the ownership and management of firms is very common (Astrachan and Shanker 2003; La Porta et al. 1999).

Although fewer than 1 percent of the papers published in prominent academic business journals deal with this category of organization (Dyer 2003), the body of evidence on the topic reveals significant differences between family and nonfamily firms across several important dimensions like financial structure (for example, Mishra and McConaughy 1999), risk preferences (for example, Gómez-Mejía et al. 2007), corporate governance (for example, Bammens, Voordeckers, and Van Gils 2011), and innovation (for example, De Massis et al. 2013) among others. From the strategic management perspective, these differences should be 
manifest in performance differences between family and nonfamily firms (Chrisman, Chua, and Sharma 2005; Chua, Chrisman, and Sharma 1999).

However, the relationship between family involvement and firm performance is far from being clear (Gedajlovic et al. 2012; Mazzi 2011; O'Boyle, Rutherford, and Pollack 2010). From the theoretical point of view, scholars continue to be divided between those emphasizing the benefits of family involvement (Chrisman, Chua, and Litz 2004; Dyer 2006; Miller et al. 2007) and those pointing to its drawbacks (for example, Schulze, Lubatkin, and Dino 2002, 2003a, b). In addition, empirical research continues to provide variegate findings (Dyer 2006; Gedajlovic et al. 2012; O'Boyle, Pollack, and Rutherford 2011; Rutherford, Kuratko, and Holt 2008), which also reflects a number of caveats in existing research. Indeed, the majority portion of previous research on this topic has investigated the differences in the performances of family and nonfamily firms dichotomously (for example, Daily and Dalton 1992; McConaughy, Matthews, and Fialko 2001), but the findings of these studies reflect the difficulties associated with the unequivocal definition of "family firms" and with the effective operationalization of such definition (Astrachan, Klein, and Smyrnios 2002; Chua, Chrisman, and Sharma 1999; Westhead and Cowling 1998). Moreover, empirical research on family firms' performance has often measured a sole dimension of family involvement, that appears problematic because, for example, family ownership and family management may have separate, and even opposite effects on performance (Block, Jaskiewicz, and Miller 2011). Finally, while most empirical evidence has been provided on the relationship between founding family involvement and performance in large firms (see, for example, Anderson and Reeb 2003; Lee 2006; Minichilli, Corbetta, and MacMillan 2010), research conducted on small and medium family firms is still rare (Heck et al. 2008), although they play a crucial role in the world economy (Storey 1994) and 
have understandable differences, for example, in terms of chain of command from large, listed companies (Johannisson and Huse 2000). Indeed, prior research suggests that the results found for large, publicly traded firms may not hold for smaller, private firms (Miller et al. 2007).

The present study addresses these issues and adds to previous research by investigating how family ownership and family involvement in the top management team (TMT) affect the performance of an SME. By complementing the partial and overly optimistic tenets of agency theory with behavioral assumptions we develop a conceptual analysis that emphasizes the distinct effects of family ownership and family involvement in the TMT on performance, thus providing a more fine-grained understanding of the consequences of family involvement. We formulate theoretical hypotheses that go beyond the dichotomy between family and non-family firms and explore non-linear relationships between family ownership and the family involvement in the TMT, and the performance of an SME. Specifically, we propose that family ownership reduces agency costs in SMEs through facilitating monitoring of managers and discouraging managerial opportunism, up to the point to which the lack of external scrutiny engenders lack of self-control (Schulze et al. 2001) and favors myopic risk aversion and nepotism. In addition to the extent of family ownership, we also highlight the negative consequences of ownership dispersion among family members. With respect to family involvement in management, we posit that it is beneficial to an SME's performance due to the reduction of information asymmetries and the alignment between owners and managers (Jensen and Meckling 1976), plus the potential benefits of kinship relationship among top managers. Nevertheless, these advantages are likely to be offset by the low availability of diverse perspectives and knowledge in decision-making processes when family involvement is excessive. As such, we argue that balancing family and external representation both in ownership and in the TMT is beneficial to the performance of an 
SME. Finally, we discuss the contingent nature of family involvement in the TMT, arguing that both the benefits and the drawbacks associated with family management are reduced when family ownership is lower. These arguments find overall support in our empirical analysis of the relationships between family involvement and performance of 787 SMEs, that relies on continuous measures to investigate the performance consequences of multiple dimensions of family involvement (namely, family ownership, family ownership dispersion, and family involvement in the TMT).

In sum, this study advances our understanding of the influence of family involvement on the performance of an SME by presenting an enhanced theoretical examination that allows to separate the benefits and drawbacks of family involvement based on its dimensions and extent, and offers a comprehensive picture of the configurations of family involvement in ownership and management that are most favorable or adverse to SMEs' performance. Thus, this study contributes to a deeper understanding of the direct and contingent effects of family involvement on the performance of SMEs (Chrisman et al. 2012; Mazzi 2011; O'Boyle, Rutherford, and Pollack 2010), which is found to be one of the most critical determinants of their long-term survival and sustainable competitive advantage (Dyer 2006).

The remainder of the paper is organized as follows. In the next section, we expand these theoretical perspectives and develop the research hypotheses. In the third section, we describe the methodology of the research, including the sample and variables included in the analysis and the analytical techniques used. In the fourth section, we present the results. In the fifth section, we present robustness checks. In the sixth section, we discuss the results in the light of previous studies and theories, point out the limitations of the present study, and suggest directions for 
future research. Finally, we draw some conclusions and outline the implications of the present study.

\section{Theory and Development of Hypotheses}

\section{Family Involvement and SME Performance: Agency and Behavioral Assumptions}

Despite family involvement in ownership and management is very common, its effects on firm performance are still matter of debate (Gedajlovic et al. 2012; Mazzi 2011; O'Boyle, Pollack, and Rutherford 2011). Specifically, research has emphasized two alternative theories to explain the relationship between family involvement and performance. Agency theory, a leading paradigm in family business studies (Chrisman, Chua, and Sharma 2005), assumes that owners have diversified shareholdings and are thus risk neutral in their preferences for individual firm actions, whereas managers are assumed to display aversion to risk, owing to the dependence of their personal wealth (for example, employment security and income) on the firm (Donaldson 1961). This risk differential (Beatty and Zajac 1994) is at the roots of conflicts of interests between owners and managers, and it is assumed to encourage opportunistic behaviors by the part of managers. Based on these assumptions, agency theory is primarily concerned about solving conflicts of interest between owners and agents (Eisenhardt 1989). Specifically, alignment of managerial behavior to the shareholders' interests can be reached through control mechanisms that involve monitoring and bonding costs, that in turn detract from performance (Jensen and Meckling 1976). According to the model proposed by Jensen and Meckling (1976), conflicts and concurrent agency costs in private SMEs are thus expected to decrease with family involvement as, on the one hand, property rights are restricted to family owners who have the authority and control to strictly monitor managers and, on the other hand, family owners' and managers' interests are naturally aligned (Fama and Jensen 1983a). As a consequence, agency 
theory suggests that family owned and managed firms are very efficient forms of organizations (for example, Daily and Dalton 1992; Fama and Jensen 1983b).

Even if valid, the view of the world presented by agency theory ignores a good bit of the complexity of organizations. Specifically, the pessimistic assumptions of agency theory about risk aversion and the self-serving nature of managers have been argued to constitute a simplistic view of human nature (Corbetta and Salvato 2004; Daily, Dalton, and Cannella 2003). Following the call for additional perspectives to complement the partiality of agency theory (Eisenhardt 1989), Schulze, Lubatkin, and Dino (2002, 2003a, b) have criticized the application of agency theory to family firms by arguing that it oversimplifies the complex and distinctive relationships among family members involved in decision making, and they have proposed an extension of agency theory based on behavioral theory.

The behavioral theory (Cyert and March 1963) suggests that owners and managers do not have static and consistent preferences toward risk, and that they, in reality, may be less concerned with solving conflicts of interests and more concerned with managing the complexity and uncertainty associated with strategic decision making (Cyert and March 1963; Finkelstein and Hambrick 1996; Hambrick and Mason 1984; Pettigrew 1992). The main feature characterizing the behavior of owners and managers in a behavioral framework is in this respect the limited ability of organizational actors to effectively gather and process information, which requires the collection and coordination of dispersed knowledge (Argote and Greve 2007; Cyert and March 1963). The involvement of the family in ownership and management is thus primarily conceived in terms of its impact on the firm's ability to make the best decisions for the firm.

With respect to the consequences of family involvement, the behavioral theory complements the dominant agency perspective. In certain aspects, it adds to the positive portrait 
of family firms in agency theory by assuming, for example, that family members are altruistic toward future generations and that family ownership will thus benefit decision making by fostering long-term orientation and parsimony in caretaking the family's wealth (Schulze, Lubatkin, and Dino 2003b). Also, family firms are supposed to benefit from the relational potential associated with the kin relationships existing among family managers (Ensley and Pearson 2005). However, the behavioral theory also emphasizes negative consequences of family involvement such as the lack of self-control, that can lead family owners to become averse to risk and unconsciously favor decisions that harm the firm and the family (Schulze et al. 2001), and the limits in knowledge and perspectives available to the TMT that may be engendered when family members with very akin values and background occupy most of the managerial positions (Anderson and Reeb 2004).

It emerges from this debate that agency theory and the behavioral theory have a different focus, and they also differ in their underlying assumptions. Both theories, taken alone, provide only a partial representation of the effects of family involvement on the performance of an SME. Complementing the two theoretical perspectives may thus provide further insights into the direct consequences of family ownership and management on the performance of an SME, as well as into the configurations between family ownership and family management that may be best for firm performance. Following prior work (for example, Lubatkin, Ling, and Schulze 2007), in the following sections we extend and combine arguments from agency and behavioral theory to conceptually examine the effects of family ownership and family involvement in the TMT and predict their ultimate effects on the performance of an SME.

\section{Family Involvement in Ownership}


The agency literature suggests that family ownership may be beneficial to an SME's performance mainly because of concentrated ownership. In particular, as concentrated owners, family owners in private SMEs have substantial economic incentives, as well as the necessary access and authority to decision processes (Carney 2005; De Massis et al. 2011), for the close monitoring of managers, suggesting that family involvement in ownership may reduce monitoring costs and thus be beneficial to an SME's performance (Fama and Jensen 1983b). The behavioral theory, instead, assumes that firm owners (in our case, family owners) play an active role in decision making and thus influence firm choices. In this regard, research using behavioral perspectives have described family owners as long-term oriented shareholders (Le Breton-Miller and Miller 2006; Lumpkin and Brigham 2011), emphasizing their desire to pass a healthier and stronger business to future generations (James 1999; Ward 2004), and have associated family ownership to higher parsimony in caretaking the family's personal wealth (Carney 2005).

Although family ownership may bring benefits to an SMEs' performance, the positive effects described above may be offset by behavioral dysfunctions at extreme degrees of family ownership in private SMEs. In particular, Schulze et al. (2001) noted that the lack of external constraints like those exercised by the capital market scrutiny may expose family owners to deficiency of self-control. Self-control is described in the behavioral economic theory as one's ability to control her/his impulses in ways that can maximize the long-term welfare (Thaler and Shefrin 1981), and lack of self-control may cause family owners to unconsciously take actions which harm the family and the firm (Lubatkin, Ling, and Schulze 2007). This problem can be particularly severe in private firms, where owners are not exposed to the market for corporate control (Schulze et al. 2001), and it can become more serious at extreme degrees of family ownership because in this scenario other equity holders, who can exercise some control on 
family owners, tend to lose influence. As a consequence, an excessive family ownership may expose private SMEs to costs that go beyond those described by the favorable agency relationships in family firms. First, because the financial portfolios of family owners are typically undiversified, meaning that a high share of their personal wealth is tied up in the family firm (Mishra and McConaughy 1999), the absence of other sources of equity than those of the family leads to relax the assumption in agency theory that shareholders are neutral to risk, and it leads to consider some counterproductive behaviors such as myopic risk aversion. Indeed, as illiquid investors, highly concentrated family owners are likely to assign lower values to uncertain cash flows (Shleifer and Vishny 1986) and this can result, for example, in poor investment decisions, such as the avoidance of risky long-term investments in order to lower the costs of outputs (Fama and Jensen 1983a), that is the adoption of a strategy geared towards consumption (Schulze, Lubatkin, and Dino 2003a). Second, although altruism can foster a longterm perspective, lack of self-control associated with very high degrees of family ownership may expose family owners to the negative side of parental altruism (Lubatkin, Ling, and Schulze 2007). These negative aspects derive from the observation that owners/managers link the welfare of one family member to the others (Jensen 1994; Schulze, Lubatkin, and Dino 2002), suggesting that parents are likely to provide their children with secure employment and other privileges, regardless of their skills or effort. Such a nepotistic approach is likely to be limited when external controls exist, but it may flourish and favor an inappropriate use of the resources of a firm in absence of external controls, leading for example to the emergence of the 'Samaritan's Dilemma', with negative consequences for firm performance (Chrisman, Chua, and Litz 2004). In sum, complementing agency theory with behavioral assumptions leads us to predict that although the performance of a firm may be expected to improve with family involvement in 
ownership, an excessively high level of family ownership is likely to counterbalance these benefits in SMEs, where decisions are not subject to any other external scrutiny. Thus, we hypothesize:

Hypothesis 1: There is an inverted $U$-shaped relationship between the degree of family ownership and the performance of an SME, with a peak associated with moderate levels of family ownership.

In addition to the degree of family ownership, also the stage of the family involvement in ownership may affect an SME's performance. Gersick (1997) noted that family ownership tends to become dispersed over time as the owner passes her or his shares onto her or his children and the firm moves from a "controlling owner" to a "sibling partnerships" stage. ${ }^{1}$ This dispersion of ownership among sibling partners can generate new agency problems. The family members who have newly become shareholders in the firm may feel a growing sense that they have a legitimate claim to ownership of the firm, in the form of a future inheritance (Holtz-Eakin, Joulfaian, and Rosen 1993; Stark and Falk 1998). As a consequence, decision makers must respond to more heterogeneous claims (Mitchell et al. 2011). For example, family owners that are not directly involved in the business may have strong incentives to reduce risk in order to satisfy their needs for belonging and intimacy (Kepner 1991), or due to a general desire to preserve their socioemotional wealth (Gómez-Mejía et al. 2007). Other family members, instead, may be primarily concerned with growth and profits (Schulze, Lubatkin, and Dino 2003a). Furthermore, when the leadership is transferred to a sibling partner, (s)he may lack the necessary authority and influence over the other family members to impose her or his decisions on them. The other siblings might

\footnotetext{
${ }^{1}$ For our purposes here, family ownership dispersion is referred to as the number of controlling family members that hold equity in the firm. Low dispersion reflects that family ownership is concentrated in one or few family members, whereas high family ownership dispersion indicates that multiple family members hold ownership in the firm. It is important to note that this measure is similar to that used by Eddleston, Otondo, and Kellermanns (2008) and Le Breton-Miller, Miller, and Lester (2011) but, contrary to Schulze, Lubatkin, and Dino (2003a), we do not focus here on how the voting power is balanced among majority and minority family owners.
} 
also try to influence the controlling owner, leading to suboptimal decision-making and distorted investment preferences, as well as poor performance. In view of the foregoing, the degree of dispersion of ownership among family members is likely to affect performance. Thus, we propose:

Hypothesis 2: There is a negative relationship between the dispersion of ownership among family members and the performance of an SME.

\section{Family Involvement in the TMT}

The involvement of family members in the top management team is a distinct dimension of family involvement and it may also have distinct consequences for the performance of an SME (Block, Jaskiewicz, and Miller 2011). Agency theory, emphasizing the importance of the conflicts of interest between owners and managers due to their divergent preferences and asymmetric information (Eisenhardt 1989), suggests that family involvement in management may generally diminish the agency costs incurred to discipline the agents' behavior (Fama and Jensen 1983b; Jensen and Meckling 1976). This is expected to happen naturally because some family owners may be also actively involved in management, or indirectly, because family members, regardless of their involvement in ownership, are tied by kinship obligations that act as a binding normative moral order aligning the family agents' interests (Chrisman, Chua, and Litz 2004; Stewart 2003). In addition, the long-term incentives shared by family members act as a mechanism reducing information asymmetries between family owners and managers in terms of opportunities for growth and awareness of risk (Gómez-Mejía, Larraza-Kintana, and Makri 2003). In sum, the moral hazard risks associated with the incentive of managers to behave opportunistically by taking non-pecuniary benefits or misallocating resources at the expense of shareholders are expected to decrease with increasing degrees of family involvement in management. 
As well as reducing agency costs, family involvement in management can be beneficial to an SME's performance also because kin relationships among managers may allow to economize on the relationship potential such as similarity, proximity, and prior acquaintance (Ancona and Caldwell 1992; Gruenfeld et al. 1996), providing benefits in terms of positive affection, smooth interaction, and commitment (Jackson 1992). Thus, the long-term nature of families can be considered as a cultural environment that promotes substantive discussion and reduces or helps to resolve disruptive relational issues better than in a nonfamily setting (Ensley and Pearson 2005), leading to superior cohesion (Gruenfeld et al. 1996) and group value consensus (Jehn 1994) among family managers.

In view of the forgoing, the performance of an SME may benefit from family involvement in management. However, research adopting the behavioral perspective also reveals some negative consequences arising from family involvement in management, that may be especially relevant when such involvement is very high. In particular, when considering the TMT as a problem-solving institution that must reduce uncertainty, the composition of top managers becomes a relevant predictor of the team's ability to generate cognitive conflict (Amason 1996). In this regard, the mutuality among family members may manifest itself as a desire to accommodate other team members for the "good' of the team (Amason and Sapienza 1997), and it may result, in absence or very little representation of non-family managers, in the avoidance of the thorough examination of alternative solutions (Janis 1982). Also, the generation of alternative ideas may be compromised in TMTs with extreme degrees of family involvement because dissenters may be ostracized (Williams 1997). As a consequence, excessive levels of family involvement in the TMT may turn into a limited availability of diverse knowledge and perspectives (Lau and Murnighan 1998), that are regarded to be functional and necessary for 
decision quality (Amason 1996; Jehn 1995; Nemeth 1986), and expose the TMT to the threat of groupthink (Janis 1982).

These arguments may be of particular relevance to SMEs, that typically have limited availability of knowledge, skills, and perspectives, and that may thus especially benefit from the aid of outsiders (Robinson 1982). For instance, anecdotal evidence suggests that when a small family firm is growing the number and complexity of required decisions increase, and the number of family members who are willing and able to make them is limited (Chua, Chrisman, and Bergiel 2009). Complementing family managers with management professionals from outside the familial network may thus reduce any potential deficiencies in a family firm's human capital (Block, Jaskiewicz, and Miller 2011; Sciascia and Mazzola 2008), providing the TMT with the diversity of perspectives and necessary skills that are needed for quality decisionmaking.

It follows that the family ratio in the TMT - defined as the ratio of family members to outsiders on the TMT (Minichilli, Corbetta, and MacMillan 2010; Pieper, Klein, and Jaskiewicz 2008) - can be considered as an important indicator of the TMT ability to generate quality decision-making in SMEs. The combination of agency and behavioral considerations suggests that the effectiveness of a TMT is best at moderate levels of family ratio in the TMT (that is, when family and non-family managers coexist in the TMT) because this group composition ensures some alignment between owners and managers and an adequate level of intra-group cohesion, as well as a sufficient degree of cognitive diversity in the TMT (Hoffman 1959; Wanous and Youtz 1986). Accordingly, we propose:

Hypothesis 3: There is an inverted $U$-shaped relationship between the family ratio in the TMT and the performance of an SME, with a peak occurring at moderate levels of family ratio in the TMT. 


\section{The Contingent Nature of Family Involvement in the TMT}

The discussion provided in the previous section, that focused on the alignment between owners and managers and the behavioral aspects of decision-making in the TMT to explain why family involvement in the TMT affects the performance of an SME, also suggests that the relationship between the family ratio in the TMT and the performance of an SME is likely to be contingent on the degree of family ownership. Indeed, it is reasonable to expect both benefits and drawbacks of family involvement in the TMT to be amplified for high levels of family ownership, whereas low family ownership is likely to relax the effects of family involvement in the TMT on firm performance. Thus, we also explore conceptually the interactive effect of family involvement in ownership and management on performance.

First, the benefits of alignment between owners and managers deriving from family involvement in the TMT, that depend on the reduced information asymmetries among owners and managers and on the family managers' disincentives to free ride on the firm's resources, are likely to be more prominent when the family owns a significant amount of ownership. Similarly, the benefits of cohesion among family members are more prominent when family ownership is high, because family involvement in ownership creates a common set of beliefs and values among family members, that entail the pursuance of shared family-centered goals (Chrisman et al. 2012). In contrast, if family ownership is considerably lower family managers grow an incentive to act opportunistically for the family and expropriate other non-family shareholders (Anderson and Reeb 2004; La Porta et al. 1999), because altruism among family members is typically not extended outside the family circle (Stewart 2003). For example, "principalprincipal" agency problems have been observed in SMEs in the occurrence of transition from family to professional management (Daily and Dalton 1992; Daily and Dollinger 1992). As a 
consequence, in the case of lower family ownership the conflicts of interest between the family and outside shareholders are likely to reduce the family managers' incentives to benefit the owners, and to engender a new set of agency costs including mutual monitoring and opportunity costs (Young et al. 2008) that offset the benefits of family involvement in the TMT.

Second, also the negative effects addressed at extreme levels of family involvement in the TMT are more relevant in the case of high degrees of family ownership, whereas they are less pronounced when family ownership is low. When family ownership is high the lack of selfcontrol entails a great ambiguity for evaluating managers' decisions and activities (Schulze, Lubatkin, and Dino 2003a), causing adverse selection problems - the agency costs associated with lack of ability as opposed to lack of effort (Fama and Jensen 1983a) - and managerial entrenchment, whereby managers can make themselves valuable to shareholders and costly to replace (Morck, Stangeland, and Yeung 1998; Oswald, Muse, and Rutherford 2009; Shleifer and Vishny 1989). Also, the degree of family identification and personal investment in the firm by family managers depends on the level of family ownership, that determines the degree to which the family and organizational domains are isomorphic (Gersick et al. 1999; Kelly, Athanassiou, and Crittenden 2000). On the contrary, when family ownership is lower, family managers are likely to embrace a wider variety of beliefs and values and display diverse perspectives since the owning family's ability to impose a homogeneous family vision on the organization is inferior (Chrisman et al. 2012). In this situation, even a TMT entirely composed of family members may dispose of a sufficient degree of members' diversity and ensure adequate quality to decision making.

In view of the foregoing, both the positive and negative effects of family involvement in the TMT are expected to be more manifest when family involvement in ownership is high, and 
we thus expect that the relationship between the family ratio in the TMT and the performance of an SME will be contingent on the degree of family ownership. Hence, we propose:

Hypothesis 4: The effect of the family ratio in the TMT on the performance of an SME is contingent on the degree of family ownership, such that the relationship will be stronger for higher levels of family ownership.

\section{Methodology}

\section{Sample Selection}

Our hypotheses were all tested using information on Italian SMEs. We adopted the European Commission's definition of SMEs; for our sample, we therefore selected firms of between 10 and 250 employees and with total annual revenues of between 2 and 50 million Euros. Italy is reported to be a heterogeneous country with respect to enterprise demographics, especially in the manufacturing industry. For example, previous studies found significant differences in the performances of Italian companies located in different geographical areas (Caselli and Di Giuli 2010). Accordingly, we further restricted the selection of firms to a limited geographical area, namely the Northern Italian province of Bergamo, in order to obtain a homogeneous sample. By applying these selection criteria, we collected information about the performance, ownership, and composition of the TMT, together with other characteristics of 787 SMEs in Bergamo. The industry breakdown according to the first digit of the industry US SIC code of the firm is provided: 12.7 percent of the sample SMEs operate in the mining and construction industries, 19.6 percent in the food and chemicals industries, 44.1 percent in the manufacturing industry, 5.5 percent in the transportation industry, and 18.1 percent in the stores and retail industries.

All data were obtained from the Italian Digital Database of Companies (AIDA). In order to improve the accuracy of this dataset, and given that information on the ownership structures 
and composition of TMTs is typically less complete in private firms than it is in public ones (Wortman 1994), we used the information reported in the balance sheets of the selected firms in order to double-check the accuracy of the data. These financial records are official documents that are registered at the Italian Chamber of Commerce and therefore have a high degree of accuracy and reliability. In addition, a telephone survey was conducted on a sub-sample of randomly selected firms $(\mathrm{N}=100)$ for robustness checks on those variables related to the family sphere. A detailed description of the variables and measures employed in the study is reported in the next section.

\section{Variables and Measures}

Our hypotheses were tested using regression analysis through the use of the variables described below.

Dependent Variable. Return on Assets (ROA) is used to assess performance, defined as the net operating income before extraordinary items, divided by total assets. The measurement of the performances of SMEs using ROA is widely supported in the literature, and has particularly been suggested for manufacturing firms (for example, Carpenter 2002), which are dominant in Northern Italy (Goodman and Bamford 1989) and therefore form a sizable proportion of our sample population. In addition, the reviews by Dyer (2006) and Holt et al. (2012) show that ROA is the most widely used performance variable in the family business literature, and it is generally considered to be the key performance indicator of family businesses (Minichilli, Corbetta, and MacMillan 2010) and of managers in general. Alternative measures of firm performance were used for robustness checks, that is Return on Equity (ROE), defined as the ratio between the net income and equity, and Return on Sales (ROS), defined as the net operating income before extraordinary items, divided by total sales. All dependent variables refer to the 
end of 2009, and additional robustness checks were also run with the performance observed in 2008. Moreover, all performance measures were adjusted for industry effects by subtracting the median industry level in the same year in order to account for differences in market opportunities that can influence managerial activities, as well as industry-specific constraints that can affect the performances of firms (Zahra 1996).

Independent Variables. We used four independent variables for testing the hypotheses.

Family ownership was calculated as the percentage of the equity of the company held by members of either a single family or a small group of families at the end of 2008. We identified familial relations among shareholders from their family name(s) (for example, Arosa, Iturralde, and Maseda 2010; Gómez-Mejía, Nunez-Nickel, and Gutierrez 2001; Rutherford, Kuratko, and Holt 2008) and determined an owning family when at least two shareholders had the same family name. This approach thus used a narrow definition of "family" because it disregarded extended familial relationships between people with different surnames (Villalonga and Amit 2006). Nevertheless, we attempted to extend our narrow definition and thereby improve the quality of our dataset by classifying up to three different families as a single one in cases where at least two shareholders had the same family name, consistently with previous definitions of family business accounting for the presence of a small number of families (Chua, Chrisman, and Sharma 1999). When the equity in a firm was partially or totally owned by other companies, we calculated the percentage of the indirect ownership of each family member from the balance sheets of the owning companies, and added it to the overall level of family-owned equity in order to measure the actual family ownership as a continuous variable. Moreover, a dummy variable (familyowned) was also created and took the value of one if family ownership was greater than 50 
percent (for example, Westhead and Cowling 1997), and 0 otherwise. Alternative measures and additional controls for family ownership are presented in the Robustness Checks section.

Family ownership dispersion was calculated as the Herfindahl index, with the polarities reversed because the Herfindahl index is originally a measure of concentration rather than dispersion (see Miller, Le Breton Miller, and Lester 2010), calculated as the sum of the squared ownership share of each family owner (relative to the total family ownership) at the end of the year 2008, that ranges by construction between zero and 100 percent. Low values indicate that family ownership in concentrated in few hands, whereas high values indicate the presence of many family owners.

Family ratio in the TMT was the proportion of family members serving as top managers divided by the total number of members of the TMT at the end of the year 2008. Although the identification of a measure to operationalize top management team is not univocal (Carpenter, Geletkanycz, and Sanders 2004), we identified a TMT as the group of top managers in the firm, including the $\mathrm{CEO}$, the $\mathrm{CFO}$, and other top managers, consistently with a number of previous studies (for example, Ferrier 2001; Kor 2003). TMTs in the sample firms were composed on average of 3.5 members. When a single person was found to hold more than one managerial position, we counted her or him only once (in both the numerator and the denominator). For each firm, a member of the top management team was considered as a family member if her/his family name corresponded to the name of one of the owning family(ies). This information was obtained from the AIDA database, that reports the names and positions assumed by each top manager within the firm. Additional tests are presented in the Robustness Checks section to assess the reliability of the measures of the family ratio in the TMT. 
Multiplicative Terms. Testing Hypotheses 1 and 3 requires that we investigate the square term of the variables family ownership and family ratio in the TMT. Testing Hypothesis 4 requires that we investigate the interaction between the family owned and family ratio in the TMT variables. To avoid the problem of multicollinearity, we used standardized values of the independent variables (described above) to calculate all multiplicative terms (Aiken and West 1991). Control Variables. We also included a number of control variables, both at the firm- and TMTlevel, in the regression models in order to rule out alternative determinants of the performance of the sampled firms. All control variables were collected from the AIDA database and referred to the year 2008.

Firm size was measured as a logarithmic transformation of the sales of the firm in order to smooth the relatively high variability in the sizes of the SMEs. The number of employees and the logarithmic transformation of the total assets of the firm were included as alternative measures for robustness checks. Firm age was taken to be the number of years between the foundation of the firm and the date when the data were obtained (that is, 2008). TMT size was measured as a logarithmic transformation of the total number of top executives in the TMT. Gender diversity was included as a dimension of demographic heterogeneity of the TMT, which may affect firm performance (Dwyer, Richard, and Chadwick 2003). The gender of each top manager was coded based on her or his name, and gender diversity was calculated in terms of Blau's (1977) heterogeneity index $\left(1-\sum i^{2}\right)$, where $i$ is the proportion of the group in the $i$ th (male and female) category. A high score on this index indicates variability in the gender among team members or gender diversity, while a low score represents greater gender homogeneity. Debt ratio was included to account for the ownership structure, that is extensively reported to affect performance (for example, Chu 2009; Demsetz and Lehn 1985). Liquidity index, defined 
as the ratio between current assets less inventories, and short-term liabilities, was introduced because SMEs with a shorter cash conversion cycle may be expected to perform better (for example, García-Teruel and Martínez-Solano 2007). Symmetrically to family ownership dispersion, non-family ownership dispersion was calculated as the Herfindahl index with the polarities reversed, calculated as the sum of the squared equity share of each non-family owner relative to the total non-family ownership at the end of the year 2008 .

\section{Results}

Table 1 shows the descriptive statistics and correlations between the variables used in this study. Sample companies earned average annual revenue of 9.5 million Euros and were on average 25 years old. We found statistically significant correlations between the variables of family ownership and family ratio in the TMT. Nevertheless, this is not a major concern since the hypotheses directly relating family ownership and family ratio in the TMT to performance were also tested separately, and the interaction effects were tested by adopting the dichotomous variable family owned, whose correlation with the family ratio in the TMT is lower than the cutoff limit of 0.7 that is allowed in regressions (Hair et al. 1998; Tabachnick, Fidell, and Osterlind 2001).

\section{Insert Table 1 about here}

We applied multiple cross-sectional OLS robust regression models to test the hypotheses. All regressions were run with the White's (1980) correction for heteroscedasticity. Table 2 shows the results of the regression models. Model A included only the control variables. Models B and C were used to test Hypotheses 1 and 2, respectively. Model D was used to test Hypotheses 3, and Model E was used to test Hypothesis 4. Finally, Model F was used as a robustness check (discussed below). The variance inflation factors (VIF) were calculated for all 
variables in the regression models. The average VIF values are very close to 1 for all models, and the maximum VIF value was 4.23 (Model F), suggesting that multicollinearity is not a problem. As regards the control variables, firm size had a positive and significant effect in all the models, whereas the effect of firm age was not significant; TMT size was not significant, whereas gender diversity had a positive, slightly significant, effect on ROA; the debt ratio and the liquidity index had both a significant impact. Model B supported the inverted U-shaped relationship between family ownership and performance proposed in Hypothesis 1. Model C supported Hypothesis 2, which proposed a negative effect of family ownership dispersion on performance. Model D supported Hypothesis 3 consistent with the idea of an inverted U-shaped relationship between TMT family ratio and performance. Finally, results from Model E imply the existence of a significant moderating effect of family ownership on the relationship between the family ratio in the TMT and the performance of an SME such that the inverted U-shaped relationship was stronger for higher levels of family ownership, consistent with Hypothesis 4.

\section{Insert Table 2 about here}

The effect of family ownership on performance was plotted using the STATA software for those firms where family ownership dispersion is low (that is, when a single family member owns more than 50 percent of ownership) and those firms where it is high (that is, when family ownership is shared among multiple family members and each of them owns 50 percent or less of ownership), with the percentage of family ownership on the horizontal axis and industryadjusted ROA on the vertical axis (Figure 1). Although both curves followed a shape akin to that proposed by Morck and Yeung (2003), the curve was lower for firms where family ownership was dispersed, showing that family ownership dispersion negatively affects an SME's performance regardless of the amount of family ownership. 


\section{Insert Figure 1 about here}

In a next step, we plotted the relationship between the family ratio in the TMT and the industry-adjusted ROA for those firms where family ownership is equal to or higher than 51 percent and those where family ownership is lower (Figure 2). The figure shows that an inverted U-shaped relationship exists between the family ratio in the TMT and the performance in firms with higher family ownership, while the family ratio in the TMT is less important for performance in firms with a lower degree of family ownership.

\section{Insert Figure 2 about here}

\section{Robustness Checks}

In order to check the robustness of the results presented in the previous section, we performed tests that address possible concerns of reliability of the findings, and we evaluated the robustness of results to various alternative specifications.

First, we estimated the post-hoc powers of the regression models. We found a very high post-hoc power for all models. They were close to 1 and, according to Cohen (1988), this implies that our results can be considered reliable. The adjusted $\mathrm{R}^{2}$ ranged between 20.4 percent in Model A to 23.9 percent in Model E. These values are higher than those found in previous studies on the performance of private SMEs (for example, Chrisman, Chua, and Litz 2004; Oswald, Muse, and Rutherford 2009; Sciascia and Mazzola 2008), but the relatively low change of $\mathrm{R}^{2}$ in Models $\mathrm{B}$ through $\mathrm{E}$, as compared to benchmark Model $\mathrm{A}$ (total $\Delta \mathrm{R}^{2}=3.5$ percent) suggests that the performance effect of family involvement is relatively small. To further address possible concerns about low increase in $\mathrm{R}^{2}$, we ran all the regressions without including the control variables. The results, that are reported in Table 3, do not differ substantially from those reported in Table 2, and thus provided further support to the hypothesized relationships. The 
maximum VIF was found for Model F' (VIF value $=4.65$ ). Model B' and Model D' were only slightly significant (adjusted $\mathrm{R}^{2}=0.017$ and adjusted $\mathrm{R}^{2}=0.020 ; \mathrm{p}<0.10$ ); Model $\mathrm{C}^{\prime}$ explained 2.4 percent of total variance and was significant at $\mathrm{p}<0.05$; finally, Model E' and Model F' were significant at $\mathrm{p}<0.01$ and explained 3.8 percent and 4.3 percent of total variance, respectively. Moreover, the coefficients found in these models were slightly more significant than those reported in Table 2, suggesting that studies that do not use control variables tend to overestimate the effects of family involvement.

\section{Insert Table 3 about here}

Second, we performed a sensitivity analysis by using alternative measures of performance, namely the industry-adjusted return on equity (ROE) and the industry-adjusted return on sales (ROS). The results were similar although less significant than those obtained using the industry-adjusted ROA. In particular, Hypothesis 1 was confirmed using both ROE and ROS as dependent variable in Model B and in Model C ( $<<0.10)$; Hypothesis 2 in Model C was confirmed although the coefficient for family ownership dispersion was less significant using ROE and ROS ( $p<0.05$ in both cases); Hypothesis 3 in Model D was confirmed, but the coefficient for family ratio in the TMT was less significant $(\mathrm{p}<0.10)$ when using ROS as dependent variable; finally, Hypothesis 4 was confirmed with the same significance level using ROE as dependent variable, but the significance level of both the interaction terms was lower ( $\mathrm{p}<0.10)$ using ROS. Moreover, all results were robust to the use of both 2008 and 2009 performance data.

Third, we ran Model F (see Table 2) in which we included the variables relative to family ownership and family ratio in the TMT together, as their high correlation may affect the results. 
Overall, our results were confirmed, although the inverted U-shaped relationship was slightly less significant than in Model C $(\mathrm{p}<0.10)$.

Fourth, the interaction term was regressed by adopting alternative measures of the variable Family owned (the threshold level was set to 30, 40 and 60 percent of family ownership), consistent with recent calls for comparing different construction methodologies for defining family firms (Mazzi 2011). In the cases of 40 and 60 percent our previous findings were still significant, while the interaction was not significant in the case of 30 percent family ownership.

Fifth, we checked for the sensitivity of the findings to the use of alternative measures for firm size. We adopted both the logarithmic transformation of firm assets and the number of employees, and our conclusions regarding the hypotheses did not change, although in the first case the coefficient for firm size was less significant $(\mathrm{p}<0.10)$ than using the logarithmic transformation of firm revenues, and in the second case the coefficient was not significant.

Sixth, although the identification of family relations on the basis of people's family name is common (for example, Arosa, Iturralde, and Maseda 2010; Gómez-Mejía, Nunez-Nickel, and Gutierrez 2001; Mazzi 2011; Rutherford, Kuratko, and Holt 2008), it entails the risk of disregarding extended familial relationships between people with different surnames (Villalonga and Amit 2006). We thus collected additional information about family ownership, family ownership dispersion, and family ratio in the TMT in order to ensure that our proxies adequately captured the appropriate attributes. In particular, a survey was conducted in September 2011 with the support of the CYFE - Center for Young and Family Enterprise - of the University of Bergamo as a telephone poll on one hundred firms that were randomly selected from our original sample. Given that all the required information refers to objective data, we judged it appropriate 
to have one respondent as a key informant in the TMT for each firm involved in the survey. In order to obtain the highest possible response, the request for participation first emphasized the importance of our research and engaged the respondent's interest in the topic. Respondents were informed about our definitions of family firm and TMT, and they were asked to confirm or to correct our information about family involvement in ownership and in the TMT. The phone calls lasted 5 to 15 minutes and we received responses from 61 firms, that is well above the typical results obtained by surveys on top managers (Pettigrew 1992). Then, results were compared with the data obtained from our secondary sources through a Kruskal-Wallis test. The results showed no significant differences between the data obtained from secondary sources and those provided by respondents $(\mathrm{p}=.993)$, thus confirming the reliability of the information used in our analyses.

Finally, we ran again all the regressions in order to check for the sensitivity of the results to the use of alternative measures for the independent and control variables. First, family ownership was alternatively measured as the sum of shares owned by the members of (i) the only family with the majority of shares, (ii) up to two families, and (iii) up to four families. All analyses confirmed our results since the coefficients' signs did not change and their significance was almost unaffected, although the coefficients were slightly different. Second, family ownership dispersion was alternatively measured as the number of family members that held equity in the firm at the end of 2008. The adoption of this measure resulted in similarly significant coefficients, thus confirming our main analysis.

\section{Discussion}

The purpose of this study was to examine the consequences of family involvement on the performance of an SME. Theoretically, we complemented the partial view offered by agency theory with assumptions of the behavioral theory in order to formulate hypotheses relating 
family ownership and family involvement in the TMT to the performance of an SME. As such, our study responds to the call for applying multiple and combined perspectives to the investigation of the relationship between family involvement and firm performance (Chrisman, Chua, and Sharma 2005; Mazzi 2011), and it benefits from this approach in offering a more nuanced understanding of the relationships of interest. Consistent with the hypothesized relationships, the analyses of 787 private SMEs supported the existence of non-linear performance effects of family ownership and family involvement in the TMT. These results not only replicate prior findings (for example, Anderson and Reeb 2003) in the context of SMEs, but also extend previous research (for example, Miller et al. 2007) that found inconsistent effects of family ownership between large and smaller firms. Overall, our results suggest that a curvilinear relationship is apt to capture the benefits and drawbacks of family ownership in small and medium private firms better than a linear relationship or the dichotomous analysis of the differences between family and non-family firms. As a consequence, this study helps solving the inconsistencies in previous research suggesting that rather than focusing on whether family involvement has a uniformly positive or negative effect on firm performance, scholars and managers should instead attempt to identify the amount of family involvement that is optimal in an organization. In other words, our conceptual analysis advises that being a family firm can be both beneficial and destructive to an organization's performance, depending on the degree of family involvement. In addition to pointing to the existence of a curvilinear relationship between family ownership and SMEs' performance, the study indicated that not only the degree, but also the structure of family ownership (that is, how family ownership is distributed among family members) can be relevant to firm performance, and that the effect of family involvement in the TMT is likely to be contingent on the degree of family ownership. Thus, our study makes a 
contribution to refine our understanding of the complexity characterizing the effects of family involvement on firm performance, especially in the case of SMEs (Chrisman et al. 2012; Mazzi 2011; Rutherford, Kuratko, and Holt 2008)

Our study also enriches the theoretical lens through which researchers can examine the effects of family involvement on firm performance in a number of ways. First, consistent with the classical arguments of agency theory, our findings suggest that family ownership may decrease overall agency problems (Fama and Jensen 1983b; Jensen and Meckling 1976), but they also refine the agency perspective by bringing support to the idea that behavioral dysfunctions can arise for very high levels of family ownership. Second, our findings suggest that the agency costs encountered in the decision-making process of a small family firm increase with the degree of dispersion of ownership among family members. This result supports the idea that family ownership is beneficial to the firm until an excessive number of family members with presumably more heterogeneous interests gets involved in ownership, as it happens for example when a small family firm ages and grows to a medium-sized company (Oswald, Muse, and Rutherford 2009).

Also the existence of an inverted U-shaped relationship between the family ratio in the TMT and performance has important implications for theory. This finding is intriguing because this is one of the very few studies that have empirically explored family involvement in management as a continuous variable. To our best knowledge, past research has largely considered only the linear relationship between family involvement in management and performance, and it has frequently overweighed the benefits, while neglecting the drawbacks, of such involvement (Kowalewski, Talavera, and Stetsyuk 2010; Lee 2006). For example, some studies have adopted the family status of the CEO as a proxy of family involvement in 
management (for example, Miller and Le Breton Miller 2006; Sraer and Thesmar 2007), thus simplifying the analysis and overlooking the fact that organizations implement teams to do much of the work traditionally accomplished by individuals (Gruenfeld et al. 1996). What is more, the inverted U-shape relationship found between family involvement in the TMT and the performance of an SME evidently contrasts with the other few studies that considered nonlinear effects of family involvement in management (that is, Minichilli, Corbetta, and MacMillan 2010; Sciascia and Mazzola 2008).

A possible reason for such divergence is probably due to differences in firm size. Our study focuses on SMEs, defined as companies with 10 to 250 employees and with revenues ranging between 2 and 50 million Euros. Sciascia and Mazzola (2008), who included quite more heterogeneous firms in their study (the average firm size being about 87 employees, but with standard deviation being 242), found a relationship that, although curvilinear, is monotonic negative, which puts into light the important contribution of non-family managers to family firms. Minichilli, Corbetta, and MacMillan (2010) studied large firms (with average revenues of 771 million Euros) and found a positive U-shaped relationship that the authors motivated by emphasizing the negative effects associated with relational conflicts between family and nonfamily managers. One possible explanation for this pattern of results is that in smaller firms the benefits associated with family involvement in management, namely the alignment between family managers and owners and cohesion among family managers, are more pronounced than in larger firms where both the family and the business systems are typically more complex (Chrisman et al. 2012). Also, private and business motives are more intertwined in SMEs than in larger firms (Carland et al. 1984), which once more implies that alignment and cohesion arguments have larger applicability in SMEs. Another possible explanation stems for the fact that 
firm specific knowledge and the compatibility of managers with the organization's set of values are of greater importance to SMEs, whereas the benefits of family involvement in the TMT become weaker in larger firms where access to external networks and industry specific knowledge are more critical (for example, Anderson and Reeb 2004; Freel 2000). Indeed, consistent with Chua, Chrisman, and Bergiel (2009) and Sciascia and Mazzola (2008), small family firms suffer from their limited availability of diverse knowledge, skills, and perspectives, so that complementing the managerial team with management professionals from outside the familial network may be indispensable. Thus, after a certain point of family involvement in the TMT the performance of an SME becomes lower. On the other hand, as the firm grows to a large corporation, perhaps family members become more heterogeneous, have higher access to professional education and external experiences, so that the drawbacks of family management are to decrease. In sum, our results suggest that size can be an important moderator of the relationship between family involvement and firm performance, but this relationship requires further investigation (O'Boyle, Pollack, and Rutherford 2011; Oswald, Muse, and Rutherford 2009). Specifically, future research may further develop our tentative inferences and design appropriate empirical tests to contextualize the performance consequences of family involvement according to firm size.

In addition, this is the first study to provide theory and evidence that the effect of family involvement in the TMT is contingent on the degree of family ownership, which is also relevant for theory. As reported in our robustness analyses, we found that the family ratio in the TMT is relevant to an SME's performance only when family ownership is higher than 40 percent. In our view, this provides further support to the idea that the benefits of family management derive primarily from the alignment of interests between owners and managers, plus the positive effects 
of kinship relationships within the group of managers, and that the drawbacks are associated to excessively redundant human capital of family members. Indeed, both positive and negative arguments become weaker in the case of low degrees of family ownership. However, alternative explanations may exist, that may be related to factors not considered in our analysis. For example, future research can further investigate the impact of family involvement by trying to disentangle pure family effects from other effects (e.g., ownership concentration, owner-manager alignment) that are not confined to family firms. To this end, future research needs to use creative approaches and innovative experimental designs such as, for example, Bayesian methods (Block, Jaskiewicz, and Miller 2011), that may help in disentangling these distinct, but related, effects . Also, future research may consider the existence and composition of a board of directors, that may be an important organizational body for aligning interests of owners and managers as well as providing advice and external perspectives to decision making (Bammens, Voordeckers, and Van Gils 2011; Westhead, Cowling, and Howorth 2001). Prior work suggests that, even if present, the boards of directors of SMEs tend to be significantly smaller (Pieper, Klein, and Jaskiewicz 2008) and almost entirely composed of family members (Corbetta and Montemerlo 1999; Voordeckers, Van Gils, and Van den Heuvel 2007). This is probably the reason why the board of directors is not found to mitigate the agency problems associated to family involvement (Chrisman, Chua, and Litz 2004). However, future research is needed to explore the multiple ways, for example, the appointment of independent directors or the formalization of strategic planning activities, through which SMEs can achieve alignment among agents while also including diverse perspectives into the decision making processes.

In sum, our study makes a step further in understanding the effects of family involvement on firm performance by focusing on continuous rather than dichotomous measures of family 
involvement, by separately examining the consequences of various dimensions of family involvement, and by contextualizing the effect of family involvement in the TMT. What is more, our special focus on SMEs also contributes to revealing the differences that may exist between large and small firms regarding the consequences of family involvement (O'Boyle, Pollack, and Rutherford 2011), suggesting that the potential benefits of family involvement in the TMT are more likely to be manifest in small firms.

Our results, while revealing, may have been at least partially a consequence of the characteristics of our sample and measurement techniques.

The data were collected from a population of small and medium firms based in a relatively small geographical area, and may thus not be representative of family and non-family firms in general. The problem is partially ameliorated by the fact that the population used is quite large, homogeneous and identifiable. Also, these data add international evidence to the relationship between family involvement and firm performance, that was mostly investigated in the U.S. (Dyer 2006). However, future studies should endeavor to test the performance consequences of family involvement using other samples that are perhaps more representative of the population of small firms in international settings.

We mainly relied on data gathered from secondary sources, that limited the quality of our measures of family involvement. Additional criteria for identifying family members could be considered, such as the residence at the same address or the residence at the company's registration address. Unfortunately such information was not available for this study. Even though we partially overcame this limitation by corroborating the empirical evidence with information reported in the balance sheets of firms and further testing the reliability of our data 
through a survey on a sub-sample of randomly selected firms, an extensive survey on the whole sample of firms would be desirable. Furthermore, such an extensive survey would also allow to directly collect a broad array of information that could be used to develop and test further hypotheses regarding moderating and mediating factors of the proposed relationships. For example, assessing directly the risk preferences and the altruistic intentions of owners and managers, or obtaining data about the managers' education, experience, and professional skills, and intermediate performance outcomes (for example, the performance of the TMT itself) would allow us to corroborate the underlying assumptions of our theoretical analysis and to develop and test more fine-grained hypotheses on the consequences of family involvement in ownership and in the TMT. These limitations represent as well hopeful directions for future research, that in addition may consider non-financial measures of performance, that have been said to be particularly important for family firms (Chrisman et al. 2012; Mahto et al. 2010).

Although the exclusion of the board of directors from our analysis can be justified in the light of the widespread evidence that the role of the board of directors is typically replaced by informal controls in SMEs (Pieper, Klein, and Jaskiewicz 2008; Salvato 1999), and that board of directors are rare among small Italian firms (Corbetta and Tomaselli 1996), the inclusion of this intermediate level between ownership and management would help to improve the understanding of the relationship between family involvement and firm performance.

Finally, the present analysis is cross-sectional, thus causal relationships can be questionable. In future research it would be interesting to investigate the composition of TMTs and the performance of SMEs over time in a longitudinal study in order to provide additional insights into the ways in which the evolution of the levels of family ownership and the family ratio in the TMT affect SMEs' performance. 
In light of the results of our study and the abovementioned limits that are still to be addressed, further investigation of the ways in which family involvement affects an SME's performance is an area ripe for future research.

\section{Conclusion}

In summary, the results of this study indicate that complementing the traditional agency theory with behavioral assumptions may benefit our understanding of the advantages and drawbacks of family involvement. Consistent with this combined perspective, our findings indicate the existence of curvilinear relationships between family ownership and family involvement in the TMT, and the performance of an SME. What is more, our study reveals the negative effect of ownership dispersion among family members and the contingent nature of family involvement in the TMT.

Our observations add to previous literature on family firms and small businesses by showing that family involvement consists of multiple interrelated dimensions that concur in affecting firm performance. Nonetheless, they provide a number of insights that may be helpful to business families to understand the performance consequences of family involvement in the firm and improve their firms' performance.

\section{References}

Aiken, L. S., and S. G. West (1991) Multiple Regression: Testing and Interpreting Interactions. Sage Publications, Newbury Park, CA.

Amason, A. C. (1996). "Distinguishing the Effects of Functional and Dysfunctional Conflict on Strategic Decision Making: Resolving a Paradox for Top Management Teams," Academy of Management Journal 39(1), 123-148.

Amason, A. C., and H. J. Sapienza (1997). "The Effects of Top Management Team Size and Interaction Norms on Cognitive and Affective Conflict," Journal of Management 23(4), 495-516. 
Ancona, D. G., and D. F. Caldwell (1992). "Bridging the Boundary: External Activity and Performance in Organizational Teams," Administrative Science Quarterly 37(4), 634665.

Anderson, R. C., and D. M. Reeb (2003). "Founding-Family Ownership and Firm Performance: Evidence from the S\&P 500," Journal of Finance 58(3), 1301-1327.

Anderson, R. C., and D. M. Reeb (2004). "Board Composition: Balancing Family Influence in S\&P 500 Firms," Administrative Science Quarterly 49(2), 209-237.

Argote, L., and H. R. Greve (2007). "A Behavioral Theory of the Firm-40 Years and Counting: Introduction and Impact," Organization Science 18(3), 337-349.

Arosa, B., T. Iturralde, and A. Maseda (2010). "Ownership Structure and Firm Performance in Non-Listed Firms: Evidence from Spain,” Journal of Family Business Strategy 1(2), 8896.

Astrachan, J. H., S. B. Klein, and K. X. Smyrnios (2002). "The F-PEC Scale of Family Influence: A Proposal for Solving the Family Business Definition Problem," Family Business Review 15(1), 45-58.

Astrachan, J. H., and M. C. Shanker (2003). "Family Businesses' Contribution to the Us Economy: A Closer Look," Family Business Review 16(3), 211-219.

Bammens, Y., W. Voordeckers, and A. Van Gils (2011). "Boards of Directors in Family Businesses: A Literature Review and Research Agenda," International Journal of Management Reviews 13(2), 134-152.

Beatty, R. P., and E. J. Zajac (1994). "Managerial Incentives, Monitoring, and Risk Bearing: A Study of Executive Compensation, Ownership, and Board Structure in Initial Public Offerings," Administrative Science Quarterly 39(2), 313-335.

Blau, P. M. (1977). Inequality and Heterogeneity: A Primitive Theory of Social Structure. New York: Free Press.

Block, J. H., P. Jaskiewicz, and D. Miller (2011). “Ownership Versus Management Effects on Performance in Family and Founder Companies: A Bayesian Reconciliation," Journal of Family Business Strategy 2(4), 232-245.

Carland, J. W., F. Hoy, W. R. Boulton, and J. A. C. Carland (1984). "Differentiating Entrepreneurs from Small Business Owners: A Conceptualization," Academy of Management Review 9(2), 354-359.

Carney, M. (2005). "Corporate Governance and Competitive Advantage in Family-Controlled Firms," Entrepreneurship Theory and Practice 29(3), 249-265.

Carpenter, M. A. (2002). "The Implications of Strategy and Social Context for the Relationship between Top Management Team Heterogeneity and Firm Performance," Strategic Management Journal 23(3), 275-284.

Carpenter, M. A., M. A. Geletkanycz, and W. Sanders (2004). "Upper Echelons Research Revisited: Antecedents, Elements, and Consequences of Top Management Team Composition," Journal of Management 30(6), 749-778.

Caselli, S., and A. Di Giuli (2010). "Does the CFO Matter in Family Firms? Evidence from Italy," European Journal of Finance 16(5), 381-411.

Chrisman, J. J., J. H. Chua, and R. A. Litz (2004). "Comparing the Agency Costs of Family and Non Family Firms: Conceptual Issues and Exploratory Evidence,” Entrepreneurship Theory and Practice 28(4), 335-354. 
Chrisman, J. J., J. H. Chua, A. W. Pearson, and T. Barnett (2012). "Family Involvement, Family Influence, and Family Centered Non Economic Goals in Small Firms," Entrepreneurship Theory and Practice 36(2), 267-293.

Chrisman, J. J., J. H. Chua, and P. Sharma (2005). "Trends and Directions in the Development of a Strategic Management Theory of the Family Firm," Entrepreneurship Theory and Practice 29(5), 555-576.

Chu, W. (2009). "The Influence of Family Ownership on Sme Performance: Evidence from Public Firms in Taiwan," Small Business Economics 33(3), 353-373.

Chua, J. H., J. J. Chrisman, and E. B. Bergiel (2009). "An Agency Theoretic Analysis of the Professionalized Family Firm," Entrepreneurship Theory and Practice 33(2), 355-372.

Chua, J. H., J. J. Chrisman, and P. Sharma (1999). "Defining the Family Business by Behavior," Entrepreneurship Theory and Practice 23(4), 19-39.

Cohen, J. (1988). Statistical Power Analysis for the Behavioral Sciences. Hillsdale, NJ: Lawrence Erlbaum.

Corbetta, G., and D. Montemerlo (1999). "Ownership, Governance, and Management Issues in Small and Medium Size Family Businesses: A Comparison of Italy and the United States," Family Business Review 12(4), 361-374.

Corbetta, G., and C. Salvato (2004). "Self Serving or Self Actualizing? Models of Man and Agency Costs in Different Types of Family Firms: A Commentary on "Comparing the Agency Costs of Family and Non Family Firms: Conceptual Issues and Exploratory Evidence"," Entrepreneurship Theory and Practice 28(4), 355-362.

Corbetta, G., and S. Tomaselli (1996). "Boards of Directors in Italian Family Businesses," Family Business Review 9(4), 403-421.

Cyert, R. M., and J. G. March (1963). A Behavioral Theory of the Firm. Englewood Cliffs, NJ: Prentice-Hall.

Daily, C. M., and D. R. Dalton (1992). "Financial Performance of Founder-Managed Versus Professionally Managed Small Corporations," Journal of Small Business Management 30(2), 25-34.

Daily, C. M., D. R. Dalton, and A. A. Cannella (2003). "Corporate Governance: Decades of Dialogue and Data," Academy of Management Review 28(3), 371-382.

Daily, C. M., and M. J. Dollinger (1992). "An Empirical Examination of Ownership Structure in Family and Professionally Managed Firms," Family Business Review 5(2), 117.

Debicki, B. J., C. F. Matherne, F. W. Kellermanns, and J. J. Chrisman (2009). "Family Business Research in the New Millennium," Family Business Review 22(2), 151-166.

De Massis, A., F. Frattini, E. Pizzurno, and L. Cassia (2013). "Product Innovation in Family vs. Non-Family Firms: An Exploratory Analysis," Journal of Small Business Management, forthcoming.

De Massis, A., J. Kotlar, J. H. Chua, J. J. Chrisman, and P. Sharma (2011). "Ability and Willingness in Family Business Research: Implications for Theory and Empirical Studies," paper presented at the IFERA 11th Annual World Family Business Research Conference. Palermo, Italy.

De Massis, A., P. Sharma, J. H. Chua, J. J. Chrisman, and J. Kotlar (2012). "State-of-the-Art of Family Business Research," in Family Business Studies: An Annotated Bibliography. Eds. A. De Massis, P. Sharma, J.H. Chua and J.J. Chrisman. Northhampton, MA: Edward Elgar. 
Demsetz, H., and K. Lehn (1985). "The Structure of Corporate Ownership: Causes and Consequences," The Journal of Political Economy 93(6), 1155-1177.

Donaldson, G. (1961). Corporate Debt Capacity: A Study of Corporate Debt Policy and the Determinants of Corporate Debt Capacity. Boston, MA: Harvard University Press.

Dwyer, S., O. C. Richard, and K. Chadwick (2003). "Gender Diversity in Management and Firm Performance: The Influence of Growth Orientation and Organizational Culture," Journal of Business Research 56(12), 1009-1019.

Dyer, W. G. (2003). "The Family: The Missing Variable in Organizational Research," Entrepreneurship Theory and Practice 27(4), 401-416.

Dyer, W. G. (2006). "Examining the Family Effect on Firm Performance," Family Business Review 19(4), 253-273.

Eddleston, K. A., R. F. Otondo, and F. W. Kellermanns (2008). "Conflict, Participative Decision Making, and Generational Ownership Dispersion: A Multilevel Analysis," Journal of Small Business Management 46(3), 456-484.

Eisenhardt, K. M. (1989). "Agency Theory: An Assessment and Review," Academy of Management Review 14(1), 57-74.

Ensley, M. D., and A. W. Pearson (2005). "An Exploratory Comparison of the Behavioral Dynamics of Top Management Teams in Family and Nonfamily New Ventures: Cohesion, Conflict, Potency, and Consensus," Entrepreneurship Theory and Practice 29(3), 267-284.

Fama, E. F., and M. C. Jensen (1983a). "Agency Problems and Residual Claims," Journal of Law and Economics 26, 327-349.

Fama, E. F., and M. C. Jensen (1983b). "Separation of Ownership and Control," Journal of Law and Economics 26, 301-325.

Ferrier, W. J. (2001). "Navigating the Competitive Landscape: The Drivers and Consequences of Competitive Aggressiveness," Academy of Management Journal, 858-877.

Finkelstein, S., and D. C. Hambrick (1996). Strategic Leadership: Top Executives and Their Effects on Organizations. St. Paul, MN: West Publishing Company.

Freel, M. S. (2000). "Barriers to Product Innovation in Small Manufacturing Firms," International Small Business Journal 18(2), 60-80.

García-Teruel, P. J., and P. Martínez-Solano (2007). "Effects of Working Capital Management on Sme Profitability," International Journal of Managerial Finance 3(2), 164-177.

Gedajlovic, E., M. Carney, J. J. Chrisman, and F. W. Kellermanns (2012). "The Adolescence of Family Firm Research: Taking Stock and Planning for the Future," Journal of Management 38(4), 1010-1037.

Gersick, K. E. (1997). Generation to Generation: Life Cycles of the Family Business. Boston, MA: Harvard Business Press.

Gersick, K. E., I. Lansberg, M. Desjardins, and B. Dunn (1999). “Stages and Transitions: Managing Change in the Family Business," Family Business Review 12(4), 287-297.

Gómez-Mejía, L. R., K. T. Haynes, M. Núñez-Nickel, K. J. L. Jacobson, and J. Moyano-Fuentes (2007). "Socioemotional Wealth and Business Risks in Family-Controlled Firms: Evidence from Spanish Olive Oil Mills," Administrative Science Quarterly 52(1), 106137.

Gómez-Mejía, L. R., M. Larraza-Kintana, and M. Makri (2003). "The Determinants of Executive Compensation in Family-Controlled Public Corporations," Academy of Management Journal 46(2), 226-237. 
Gómez-Mejía, L. R., M. Nunez-Nickel, and I. Gutierrez (2001). "The Role of Family Ties in Agency Contracts," Academy of Management Journal 44(1), 81-95.

Goodman, E. J., and J. Bamford (1989). Small Firms and Industrial Districts in Italy. New York: Routledge.

Gruenfeld, D. H., E. A. Mannix, K. Y. Williams, and M. A. Neale (1996). “Group Composition and Decision Making: How Member Familiarity and Information Distribution Affect Process and Performance," Organizational Behavior and Human Decision Processes 67(1), 1-15.

Hair, J. F., W. C. Black, B. J. Babin, R. E. Anderson, and R. L. Tatham. (1998). Multivariate Data Analysis. Englewood Cliffs, NJ: Prentice Hall.

Hambrick, D. C., and P. A. Mason (1984). "Upper Echelons: The Organization as a Reflection of Its Top Managers," Academy of Management Review 9(2), 193-206.

Heck, R. K. Z., F. Hoy, P. Z. Poutziouris, and L. P. Steier (2008). "Emerging Paths of Family Entrepreneurship Research," Journal of Small Business Management 46(3), 317-330.

Hoffman, L. R. (1959). "Homogeneity of Member Personality and Its Effect on Group ProblemSolving," The Journal of Abnormal and Social Psychology 58(1), 27-32.

Holt, D. T., A. W. Pearson, M. J. Carr, and T. Barnett (2012). "Measuring Performance in Family Businesses: The State of the Art and Roadmap for Advancing Family Business Research and Practice," paper presented at the 8th Family Enterprise Research Conference, Montreal, Canada, May.

Holtz-Eakin, D., D. Joulfaian, and H. S. Rosen (1993). "The Carnegie Conjecture: Some Empirical Evidence," The Quarterly Journal of Economics 108(2), 413-435.

Jackson, S. (1992). "Consequences of Group Composition for the Interpersonal Dynamics of Strategic Issue Processing," in Advances in Strategic Management. Eds. P. Shrivastava, A. Huff, and J. Dutton, Greenwich, CT: JAI Press, 345-382.

James, H. S. (1999). "Owner as Manager, Extended Horizons and the Family Firm," International Journal of the Economics of Business 6(1), 41-55.

Janis, I. L. (1982). Groupthink: Psychological Studies of Policy Decisions and Fiascoes. Boston, MA: Houghton Mifflin.

Jehn, K. A. (1994). "Enhancing Effectiveness: An Investigation of Advantages and Disadvantages of Value-Based Intragroup Conflict," International Journal of Conflict Management 5(3), 223-238.

Jehn, K. A. (1995). “A Multimethod Examination of the Benefits and Detriments of Intragroup Conflict," Administrative Science Quarterly 40(2), 256-282.

Jensen, M. C. (1994). "Self-Interest, Altruism, Incentives, and Agency Theory," Journal of Applied Corporate Finance 7(2), 40-45.

Jensen, M. C., and W. H. Meckling (1976). "Theory of the Firm: Managerial Behavior, Agency Costs and Ownership Structure," Journal of Financial Economics 3(4), 305-360.

Johannisson, B., and M. Huse (2000). "Recruiting Outside Board Members in the Small Family Business: An Ideological Challenge," Entrepreneurship and Regional Development 12(4), 353-378.

Kelly, L. M., N. Athanassiou, and W. F. Crittenden (2000). "Founder Centrality and Strategic Behavior in the Family-Owned Firm," Entrepreneurship Theory and Practice 25(2), 27 42.

Kepner, E. (1991). "The Family and the Firm: A Coevolutionary Perspective," Family Business Review 4(4), 445-461. 
Kor, Y. Y. (2003). "Experience-Based Top Management Team Competence and Sustained Growth," Organization Science 14(6), 707-719.

Kowalewski, O., O. Talavera, and I. Stetsyuk (2010). "Influence of Family Involvement in Management and Ownership on Firm Performance: Evidence from Poland," Family Business Review 23(1), 45-59.

La Porta, R., F. Lopez-de-Silanes, A. Shleifer, and R. Vishny (1999). "Corporate Ownership around the World," The Journal of Finance 54(2), 471-517.

Lau, D. C., and J. K. Murnighan (1998). "Demographic Diversity and Faultlines: The Compositional Dynamics of Organizational Groups," Academy of Management Review 23(2), 325-340.

Le Breton-Miller, I., D. Miller, and R. H. Lester (2011). "Stewardship or Agency? A Social Embeddedness Reconciliation of Conduct and Performance in Public Family Businesses," Organization Science 22(3), 704-721.

Le Breton-Miller, I. L., and D. Miller (2006). "Why Do Some Family Businesses out Compete? Governance, Long Term Orientations, and Sustainable Capability," Entrepreneurship Theory and Practice 30(6), 731-746.

Lee, J. (2006). "Family Firm Performance: Further Evidence," Family Business Review 19(2), 103-114.

Lubatkin, M. H., Y. Ling, and W. S. Schulze (2007). "An Organizational Justice-Based View of Self-Control and Agency Costs in Family Firms," Journal of Management Studies 44(6), 955-971.

Lumpkin, G. T., and K. H. Brigham (2011). "Long-Term Orientation and Intertemporal Choice in Family Firms," Entrepreneurship Theory and Practice 35(6), 1149-1169.

Mahto, R. V., P. S. Davis, J. A. Pearce Ii, and R. B. Robinson Jr (2010). "Satisfaction with Firm Performance in Family Businesses," Entrepreneurship Theory and Practice 34(5), 9851001.

Mazzi, C. (2011). "Family Business and Financial Performance: Current State of Knowledge and Future Research Challenges," Journal of Family Business Strategy 2(3), 166-181.

McConaughy, D. L., C. H. Matthews, and A. S. Fialko (2001). "Founding Family Controlled Firms: Performance, Risk, and Value," Journal of Small Business Management 39(1), 3149.

Miller, D., I. Le Breton-Miller, R. H. Lester, and A. A. Cannella Jr (2007). "Are Family Firms Really Superior Performers?," Journal of Corporate Finance 13(5), 829-858.

Miller, D., and I. Le Breton Miller (2006). "Family Governance and Firm Performance: Agency, Stewardship, and Capabilities," Family Business Review 19(1), 73-87.

Miller, D., I. Le Breton Miller, and R. H. Lester (2010). "Family Ownership and Acquisition Behavior in Publicly Traded Companies," Strategic Management Journal 31(2), 201-223.

Minichilli, A., G. Corbetta, and I. C. MacMillan (2010). "Top Management Teams in FamilyControlled Companies:'Familiness','Faultlines', and Their Impact on Financial Performance," Journal of Management Studies 47(2), 205-222.

Mishra, C. S., and D. L. McConaughy (1999). "Founding Family Control and Capital Structure: The Risk of Loss of Control and the Aversion to Debt," Entrepreneurship Theory and Practice 23(4), 53-64.

Mitchell, R. K., B. R. Agle, J. J. Chrisman, and L. J. Spence (2011). "Toward a Theory of Stakeholder Salience in Family Firms," Business Ethics Quarterly 21(2), 235-255. 
Morck, R., D. A. Stangeland, and B. Yeung. (1998). "Inherited Wealth, Corporate Control and Economic Growth: The Canadian Disease," in Concentrated Corporate Ownership. Eds. R. Morck. Chicago: University of Chicago Press, 319-369.

Morck, R., and B. Yeung (2003). "Agency Problems in Large Family Business Groups," Entrepreneurship Theory and Practice 27(4), 367-382.

Nemeth, C. J. (1986). "Differential Contributions of Majority and Minority Influence," Psychological Review 93(1), 23.

O'Boyle, E. H., J. M. Pollack, and M. W. Rutherford (2011). "Exploring the Relation between Family Involvement and Firms' Financial Performance: A Meta-Analysis of Main and Moderator Effects," Journal of Business Venturing 27(1), 1-18.

O'Boyle, E. H., M. W. Rutherford, and J. M. Pollack (2010). "Examining the Relation between Ethical Focus and Financial Performance in Family Firms: An Exploratory Study," Family Business Review 23(4), 310-326.

Oswald, S. L., L. A. Muse, and M. W. Rutherford (2009). “The Influence of Large Stake Family Control on Performance: Is It Agency or Entrenchment?," Journal of Small Business Management 47(1), 116-135.

Pettigrew, A. M. (1992). “On Studying Managerial Elites,” Strategic Management Journal 13(2), 163-182.

Pieper, T. M., S. B. Klein, and P. Jaskiewicz (2008). "The Impact of Goal Alignment on Board Existence and Top Management Team Composition: Evidence from Family Influenced Businesses," Journal of Small Business Management 46(3), 372-394.

Robinson, R. B. (1982). "The Importance of 'Outsiders' in Small Firm Strategic Planning," Academy of management Journal 25(1), 80-93.

Rutherford, M. W., D. F. Kuratko, and D. T. Holt (2008). "Examining the Link between 'Familiness' and Performance: Can the F-PEC Untangle the Family Business Theory Jungle?," Entrepreneurship Theory and Practice 32(6), 1089-1109.

Salvato, C. A. (1999). "Boards of Directors in Family Firms: Mimicry or Resource Dependence Reduction?," in Innovation and Economic Development: The Role of Entrepreneurship and SMEs. Eds. G. Capaldo, and M. Raffa. Naples, IT: Edizioni Scientifiche Italiane.

Schulze, W. S., M. H. Lubatkin, and R. N. Dino (2002). "Altruism, Agency, and the Competitiveness of Family Firms," Managerial and Decision Economics 23(4-5), 247259.

Schulze, W. S., M. H. Lubatkin, and R. N. Dino (2003a). "Exploring the Agency Consequences of Ownership Dispersion among the Directors of Private Family Firms," Academy of Management Journal 46(2), 179-194.

Schulze, W. S., M. H. Lubatkin, and R. N. Dino (2003b). "Toward a Theory of Agency and Altruism in Family Firms," Journal of Business Venturing 18(4), 473-490.

Schulze, W. S., M. H. Lubatkin, R. N. Dino, and A. K. Buchholtz (2001). “Agency Relationships in Family Firms: Theory and Evidence," Organization Science 12(2), 99-116.

Sciascia, S., and P. Mazzola (2008). "Family Involvement in Ownership and Management: Exploring Nonlinear Effects on Performance," Family Business Review 21(4), 331-345.

Shleifer, A., and R. W. Vishny (1986). "Large Shareholders and Corporate Control," The Journal of Political Economy 94(3), 461-488.

Shleifer, A., and R. W. Vishny (1989). "Management Entrenchment:: The Case of ManagerSpecific Investments," Journal of Financial Economics 25(1), 123-139. 
Sraer, D., and D. Thesmar (2007). "Performance and Behavior of Family Firms: Evidence from the French Stock Market," Journal of the European Economic Association 5(4), 709-751.

Stark, O., and I. Falk (1998). "Transfers, Empathy Formation, and Reverse Transfers," American Economic Review 88(2), 271-276.

Stewart, A. (2003). "Help One Another, Use One Another: Toward an Anthropology of Family Business," Entrepreneurship Theory and Practice 27(4), 383-397.

Storey, D. J. (1994). Understanding the Small Business Sector. London, UK: Thomson Learning Emea.

Tabachnick, B. G., and Fidell, L. S. (2001). Using Multivariate Statistics ( ${ }^{\text {th }}$ ed.), New York: HarperCollins

Thaler, R. H., and H. M. Shefrin (1981). "An Economic Theory of Self-Control," The Journal of Political Economy 89(2), 392-406.

Villalonga, B., and R. Amit (2006). "How Do Family Ownership, Control and Management Affect Firm Value?," Journal of Financial Economics 80(2), 385-417.

Voordeckers, W., A. Van Gils, and J. Van den Heuvel (2007). "Board Composition in Small and Medium Sized Family Firms," Journal of Small Business Management 45(1), 137-156.

Wanous, J. P., and M. A. Youtz (1986). "Solution Diversity and the Quality of Group Decisions," Academy of Management Journal 29(1), 149-159.

Ward, J. L. (2004). Perpetuating the Family Business. New York: Palgrave Macmillan.

Westhead, P., and M. Cowling (1997). "Performance Contrasts between Family and Non-Family Unquoted Companies in the Uk," International Journal of Entrepreneurial Behaviour \& Research 3(1), 30-52.

Westhead, P., and M. Cowling (1998). "Family Firm Research: The Need for a Methodological Rethink," Entrepreneurship Theory and Practice 23(1), 31-33.

Westhead, P., M. Cowling, and C. Howorth (2001). "The Development of Family Companies: Management and Ownership Imperatives," Family Business Review 14(4), 369-385.

White, H. (1980). "A Heteroskedasticity-Consistent Covariance Matrix Estimator and a Direct Test for Heteroskedasticity," Econometrica: Journal of the Econometric Society 48(4), 817-838.

Williams, K. D. (1997). "Social Ostracism," in Aversive Interpersonal Behaviors. The Plenum Series in Social/Clinical Psychology. Eds. R. M. Kowalski. New York: Plenum Press, 133-170.

Wortman, M. S. (1994). "Theoretical Foundations for Family-Owned Business: A Conceptual and Research-Based Paradigm," Family Business Review 7(1), 3-27.

Young, M. N., M. W. Peng, D. Ahlstrom, G. D. Bruton, and Y. Jiang (2008). "Corporate Governance in Emerging Economies: A Review of the Principal-Principal Perspective," Journal of Management Studies 45(1), 196-220.

Zahra, S. A. (1996). "Goverance, Ownership, and Corporate Entrepreneurship: The Moderating Impact of Industry Technological Opportunities," Academy of Management Journal 39(6), 1713-1735. 


\section{Tables and Figures}

Table 1

Descriptive Statistics and Correlations

\begin{tabular}{|c|c|c|c|c|c|c|c|c|c|c|c|c|c|c|}
\hline Variable & Mean & S.D. & 1 & 2 & 3 & 4 & 5 & 6 & 7 & 8 & 9 & 10 & 11 & 12 \\
\hline 1. Firm Size $(\log )$ & 9.17 & 0.84 & 1.00 & & & & & & & & & & & \\
\hline 2. Firm Age & 25.23 & 11.73 & 0.01 & 1.00 & & & & & & & & & & \\
\hline 3. Debt Ratio & 7.45 & 18.52 & 0.07 & $0.08 *$ & 1.00 & & & & & & & & & \\
\hline 4. Liquidity Index & 1.11 & 0.83 & -0.05 & 0.03 & -0.03 & 1.00 & & & & & & & & \\
\hline $\begin{array}{l}\text { 5. Non-family Ownership } \\
\text { Dispersion }\end{array}$ & 0.21 & 0.28 & $0.17 *$ & $0.09 *$ & -0.06 & 0.01 & 1.00 & & & & & & & \\
\hline 6. TMT Size & 0.54 & 0.27 & $0.21 * *$ & $0.16 * *$ & 0.06 & 0.04 & $0.08^{*}$ & 1.00 & & & & & & \\
\hline 7. Gender Diversity & 0.56 & 0.83 & $0.15^{* *}$ & $0.08^{*}$ & -0.01 & 0.03 & 0.06 & 0.02 & 1.00 & & & & & \\
\hline 8. Family Ownership & 0.50 & 0.41 & -0.06 & $0.13 * *$ & 0.03 & 0.02 & $-0.14 *$ & $0.07 *$ & -0.04 & 1.00 & & & & \\
\hline 9. Family Owned ${ }^{\mathrm{a}}$ & 0.54 & 0.50 & $-0.07 *$ & $0.10 * *$ & 0.02 & 0.02 & $-0.16^{*}$ & 0.04 & -0.01 & $0.81 * *$ & 1.00 & & & \\
\hline $\begin{array}{l}\text { 10. Family Ownership } \\
\text { Dispersion }\end{array}$ & 2.12 & 2.15 & 0.05 & $0.23 * *$ & 0.05 & 0.04 & 0.04 & $0.14 * *$ & $0.07 *$ & $0.65^{* *}$ & $0.47 * *$ & 1.00 & & \\
\hline 11. Family Ratio in the TMT & 0.49 & 0.40 & -0.05 & $0.12 * *$ & 0.04 & 0.03 & 0.01 & 0.02 & 0.03 & $0.79 * *$ & $0.52 * *$ & $0.60 * *$ & 1.00 & \\
\hline 12. Industry-Adjusted ROA & 0.15 & 7.57 & $0.08 *$ & -0.04 & $-0.18 * *$ & $0.36 * *$ & 0.06 & -0.03 & $0.09 *$ & 0.00 & 0.02 & -0.05 & 0.01 & 1.00 \\
\hline
\end{tabular}

$\mathrm{N}=787$

a This variable is dichotomously coded.

$* \mathrm{p}<.05$

$* * \mathrm{p}<.01$ 
Table 2

Results of Multiple Regression Analysis of Hypothesized Relationships

\begin{tabular}{|c|c|c|c|c|c|c|}
\hline Variables & Model A & $\begin{array}{c}\text { Model B } \\
\text { (H1) }\end{array}$ & $\begin{array}{c}\text { Model C } \\
\text { (H2) }\end{array}$ & $\begin{array}{c}\text { Model D } \\
\text { (H3) }\end{array}$ & $\begin{array}{c}\text { Model E } \\
(\text { H4) }\end{array}$ & Model F \\
\hline \multirow[t]{2}{*}{ Firm size (log sales) } & $1.07 * * *$ & $1.06^{* * *}$ & $1.10^{* * *}$ & $1.05^{* * *}$ & $1.10^{* * *}$ & $1.06^{* * *}$ \\
\hline & $(0.32)$ & $(0.31)$ & $(0.31)$ & $(0.30)$ & $(0.31)$ & $(0.29)$ \\
\hline \multirow[t]{2}{*}{ Age } & -0.01 & -0.02 & -0.01 & -0.02 & -0.01 & -0.01 \\
\hline & $(0.02)$ & $(0.02)$ & $(0.02)$ & $(0.02)$ & $(0.02)$ & $(0.02)$ \\
\hline \multirow[t]{2}{*}{ TMT Size } & 1.42 & 1.52 & 1.71 & 1.43 & 1.25 & 1.68 \\
\hline & $(1.12)$ & $(1.13)$ & $(1.13)$ & (1.09) & $(1.16)$ & $(1.27)$ \\
\hline \multirow[t]{2}{*}{ Gender Diversity } & $3.46^{*}$ & $3.71 *$ & $3.73 *$ & $3.25^{*}$ & $3.71 *$ & $3.28 *$ \\
\hline & $(1.59)$ & $(1.52)$ & $(1.53)$ & $(1.26)$ & $(1.51)$ & $(1.21)$ \\
\hline \multirow[t]{2}{*}{ Debt Ratio } & $-7.04 * * *$ & $-7.09 * * *$ & $-7.11 * * *$ & $-7.19 * * *$ & $-7.09 * * *$ & $-7.13 * * *$ \\
\hline & $(1.62)$ & $(1.63)$ & $(1.64)$ & $(1.64)$ & $(1.64)$ & $(1.62)$ \\
\hline \multirow[t]{2}{*}{ Liquidity Index } & $2.51^{* * *}$ & $2.51^{* * *}$ & $2.50^{* * *}$ & $2.52 * * *$ & $2.52^{* * *}$ & $2.51 * * *$ \\
\hline & $(0.30)$ & $(0.30)$ & $(0.30)$ & $(0.31)$ & $(0.30)$ & $(0.30)$ \\
\hline \multirow{2}{*}{$\begin{array}{l}\text { Non-Family Ownership } \\
\text { Dispersion }\end{array}$} & 0.02 & 0.03 & 0.03 & 0.02 & 0.03 & 0.03 \\
\hline & $(0.03)$ & $(0.04)$ & $(0.02)$ & $(0.04)$ & $(0.04)$ & $(0.02)$ \\
\hline \multirow[t]{2}{*}{ Family Ownership } & & $4.61^{*}$ & $7.88^{* * *}$ & & & $4.73 * *$ \\
\hline & & $(2.29)$ & $(2.03)$ & & & $(2.13)$ \\
\hline \multirow[t]{2}{*}{ Family Ownership ${ }^{2}$} & & $-4.25 * *$ & $-6.47 * * *$ & & & $-4.19 * *$ \\
\hline & & (1.67) & (1.93) & & & $(2.16)$ \\
\hline \multirow{2}{*}{$\begin{array}{l}\text { Family Ownership } \\
\text { Dispersion }\end{array}$} & & & $-0.36 * *$ & & & $-0.42 * *$ \\
\hline & & & $(0.10)$ & & & $(0.18)$ \\
\hline \multirow[t]{2}{*}{ Family Owned } & & & & & -0.38 & \\
\hline & & & & & $(0.36)$ & \\
\hline \multirow{2}{*}{$\begin{array}{l}\text { Family Ratio in the } \\
\text { TMT }\end{array}$} & & & & $5.23 * *$ & 0.05 & $4.82 *$ \\
\hline & & & & $(2.14)$ & $(0.10)$ & (2.31) \\
\hline \multirow{2}{*}{$\begin{array}{l}\text { Family Ratio in the } \\
\text { TMT }^{2}\end{array}$} & & & & $-4.95^{*}$ & & $-4.14 *$ \\
\hline & & & & $(2.22)$ & & $(2.49)$ \\
\hline \multirow{6}{*}{$\begin{array}{l}\text { Family Owned } x \\
\text { Family Ratio in the } \\
\text { TMT } \\
\text { Family Owned } x \\
\text { Family Ratio in the } \\
\text { TMT }^{2} \\
\text { Constant }\end{array}$} & & & & & $5.82 * *$ & \\
\hline & & & & & (1.77) & \\
\hline & & & & & $-4.73 * *$ & \\
\hline & & & & & (1.38) & \\
\hline & $-6.85^{* *}$ & $-7.06 * *$ & $-7.84 * *$ & $-6.81 * *$ & $-7.02 * *$ & $-7.14 * *$ \\
\hline & (2.98) & $(3.00)$ & (3.01) & (2.99) & (3.03) & (2.96) \\
\hline Observations & 787 & 787 & 787 & 787 & 787 & 787 \\
\hline Max VIF & 1.02 & 1.09 & 1.75 & 1.26 & 3.95 & 4.23 \\
\hline F & $31.12 * * *$ & $25.94 * * *$ & $22.72 * * *$ & $24.41 * * *$ & $18.17 * * *$ & $15.94 * * *$ \\
\hline Adj- $R^{2}$ & 0.204 & 0.218 & 0.228 & 0.221 & 0.239 & 0.251 \\
\hline
\end{tabular}

$\mathrm{N}=787$. Significance levels are based on two-tailed tests for all models and coefficients.

$* \mathrm{p}<.10 ; * * \mathrm{p}<.05 ; * * * \mathrm{p}<.01$ 
Table 3

Results of Multiple Regression Analysis Run Without Control Variables

\begin{tabular}{|c|c|c|c|c|c|}
\hline Variables & $\begin{array}{l}\text { Model B' } \\
\text { (H1) }\end{array}$ & $\begin{array}{l}\text { Model C' } \\
\text { (H2) }\end{array}$ & $\begin{array}{l}\text { Model D' } \\
(\text { H3) }\end{array}$ & $\begin{array}{l}\text { Model E' } \\
(\text { H4) }\end{array}$ & Model F' \\
\hline \multirow[t]{2}{*}{ Family Ownership } & $7.12 * *$ & $9.14 * * *$ & & & $7.74 * * *$ \\
\hline & $(1.80)$ & $(2.47)$ & & & $(1.93)$ \\
\hline \multirow[t]{2}{*}{ Family Ownership ${ }^{2}$} & $-6.45 * *$ & $-7.91 * * *$ & & & $-7.01 * * *$ \\
\hline & $(1.72)$ & $(2.38)$ & & & (1.68) \\
\hline \multirow[t]{2}{*}{ Family Ownership Dispersion } & & $-4.61 * * *$ & & & $-3.29^{* * *}$ \\
\hline & & $(0.97)$ & & & $(0.62)$ \\
\hline \multirow[t]{2}{*}{ Family Owned } & & & & $-2.63^{*}$ & \\
\hline & & & & $(0.94)$ & \\
\hline \multirow[t]{2}{*}{ Family Ratio in the TMT } & & & $6.41 * * *$ & $0.17^{*}$ & $6.21 * *$ \\
\hline & & & $(1.83)$ & $(0.09)$ & $(2.57)$ \\
\hline \multirow[t]{2}{*}{ Family Ratio in the $\mathrm{TMT}^{2}$} & & & $-5.31 * * *$ & & $-4.85 * *$ \\
\hline & & & $(1.57)$ & & $(1.72)$ \\
\hline \multirow{2}{*}{$\begin{array}{l}\text { Family Owned } \times \text { Family Ratio in the } \\
\text { TMT }\end{array}$} & & & & $4.28 * * *$ & \\
\hline & & & & $(0.76)$ & \\
\hline \multirow{2}{*}{$\begin{array}{l}\text { Family Owned } \times \text { Family Ratio in the } \\
\text { TMT }^{2}\end{array}$} & & & & $-3.96 * * *$ & \\
\hline & & & & $(0.98)$ & \\
\hline \multirow[t]{2}{*}{ Constant } & $-1.96^{* * *}$ & $-2.36^{* * *}$ & $-1.02 * *$ & $-2.61 * * *$ & $-2.49 * * *$ \\
\hline & $(-0.58)$ & $(0.71)$ & $(0.40)$ & $(0.74)$ & $(0.83)$ \\
\hline Observations & 787 & 787 & 787 & 787 & 787 \\
\hline Max VIF & 1.11 & 1.90 & 1.58 & 4.38 & 4.65 \\
\hline $\mathrm{F}$ & $2.08^{*}$ & $3.45^{* *}$ & $2.93^{*}$ & $4.61 * * *$ & $5.03 * * *$ \\
\hline Adj- $R^{2}$ & 0.017 & 0.024 & 0.020 & 0.038 & 0.043 \\
\hline $\begin{array}{l}\mathrm{N}=787 . \text { Significance levels are } \\
* \mathrm{p}<.10 \\
* * \mathrm{p}<.05 \\
* * * \mathrm{p}<.01\end{array}$ & d on tw & iled test & all mo & and coef & \\
\hline
\end{tabular}




\section{Figure 1}

Effects of Family Ownership and Ownership Dispersion on the Performance of an SME $^{\mathrm{a}}$

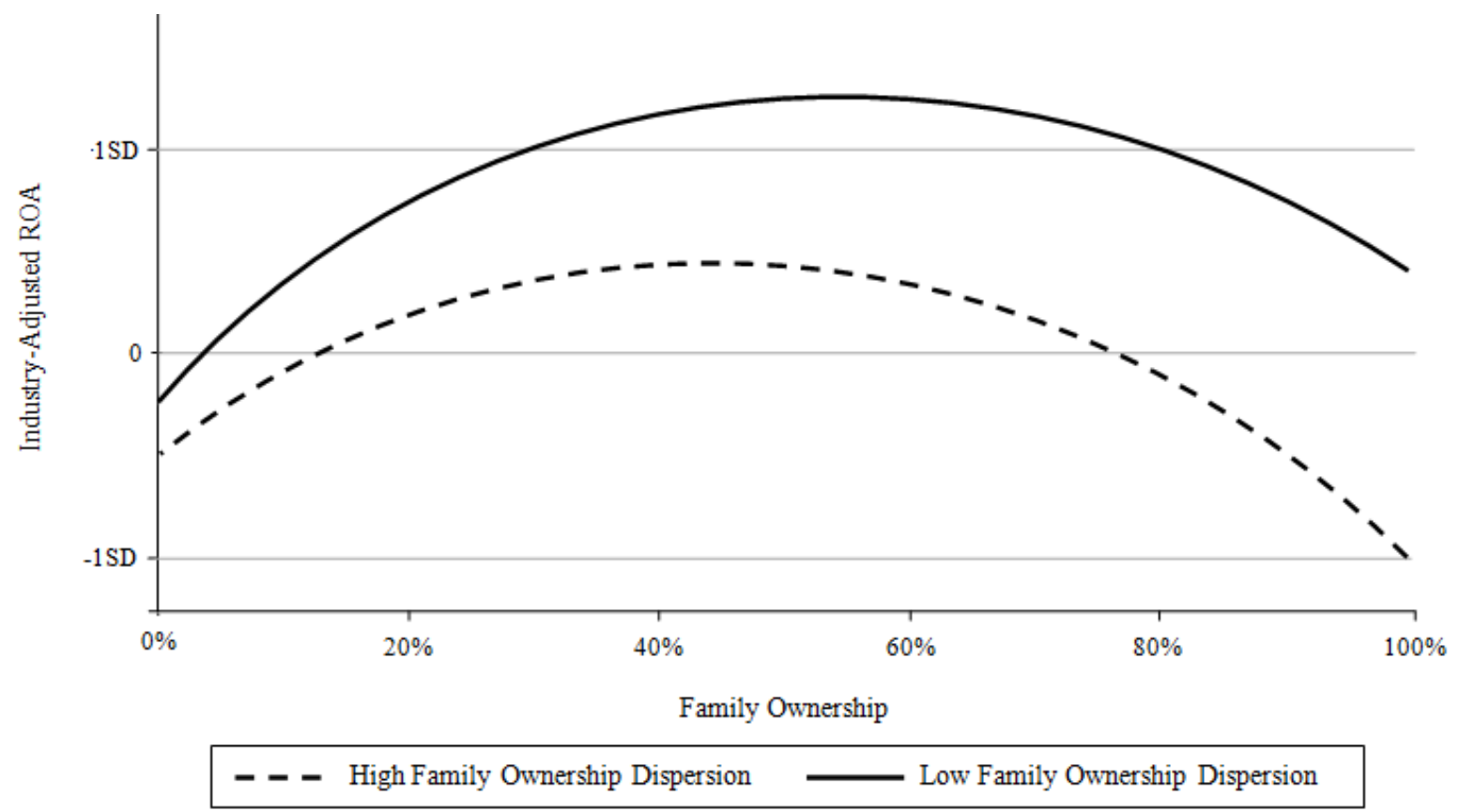

${ }^{a}$ Family ownership dispersion is arbitrary coded as low when a single family member owns more than 50 percent of ownership and high when family ownership is shared among multiple family members and each of them owns 50 percent or less of ownership.

Figure 2

Effects of the Family Ratio in the TMT on the Performance of an SME

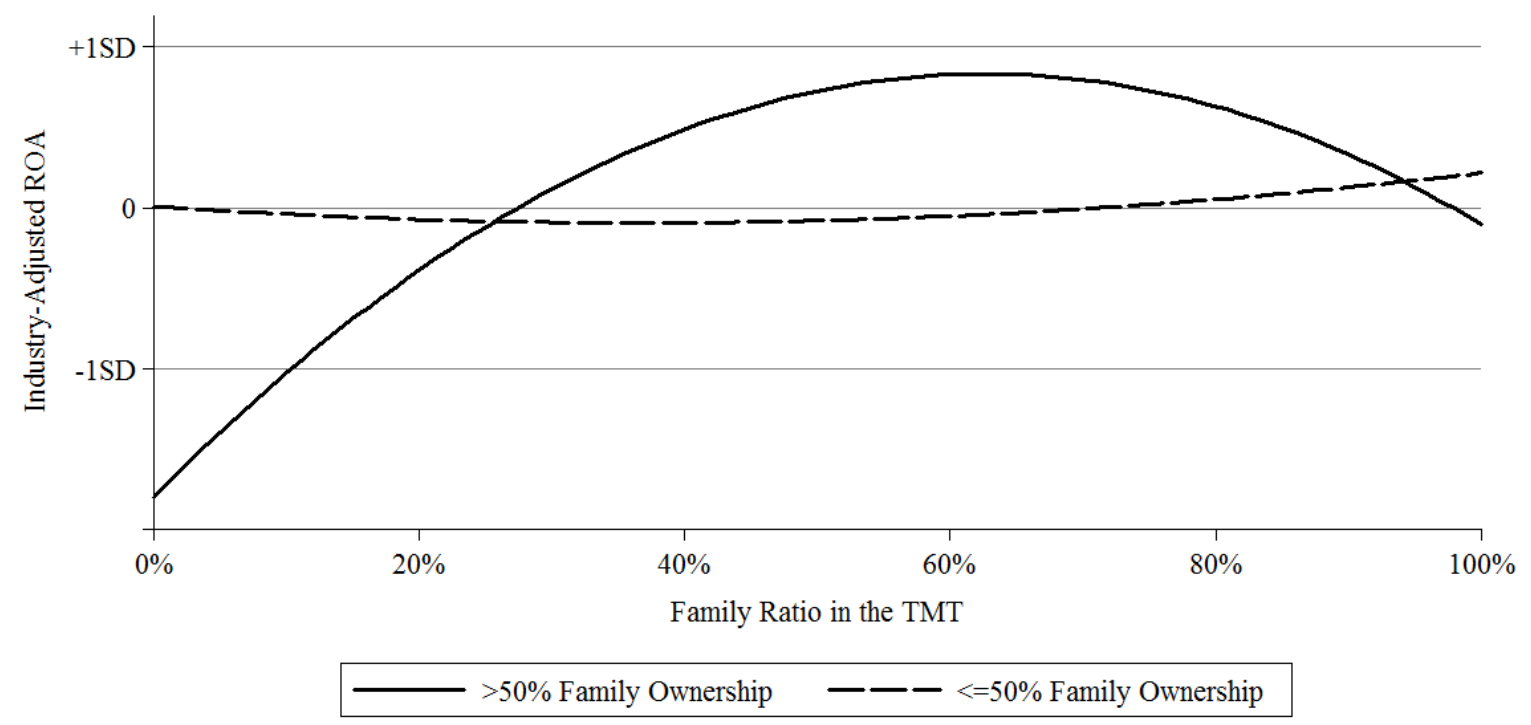

